\title{
Viral Wilt of Cucumber Plants Grafted on Squash Rootstocks
}

\author{
Mabito IWASAKI* and Tadaoki INABA*
}

\begin{abstract}
Wilt diseases were observed in cucumber plants grafted on squash rootstocks in Kagawa, Japan, in 1986. In the wilted plants, mosaic symptoms were appeared on the upper leaves whereas the stems and roots failed to exhibit symptoms. Among the 32 leaf samples collected in the field, 15 samples were infected with zucchini yellow mosaic virus (ZYMV), 9 with cucumber mosaic virus (CMV) and ZYMV, 7 with CMV, ZYMV and watermelon mosaic virus-2 (WMV-2), and 1 with CMV and WMV-2. The non-grafted cucumber plants inoculated with these samples did not show any wilt symptoms. When the grafted cucumber plants were inoculated with these samples, those containing ZYMV alone or CMV and WMV-2 caused only slight wilt at a low frequency whereas those containing CMV and ZYMV or CMV, ZYMV and WMV-2 caused severe wilt at a high frequency. To identify the causal virus of wilt, grafted and non-grafted cucumber plants were inoculated with a single isolate of CMV, ZYMV or WMV-2, and a combination of CMV and ZYMV; CMV and WMV-2; ZYMV and WMV-2; CMV, ZYMV and WMV-2, respectively. In the non-grafted cucumber plants, wilt symptoms were not observed after the inoculation in all cases. In the grafted cucumber plants, the inoculation with CMV or WMV-2, and with a combination of ZYMV and WMV-2 did not cause wilt symptoms, whereas the inoculation with ZYMV and a combination of CMV and WMV-2 caused slight wilt at a low frequency. However, the inoculation with a combination of CMV and ZYMV, or CMV, ZYMV and WMV-2 caused severe wilt on the grafted cucumber plants at a high frequency. Based on these results, it was concluded that mixed infection with CMV and ZYMV, or CMV, ZYMV and WMV-2, caused severe wilt on the grafted cucumber plants whereas single infection with ZYMV or mixed infection with CMV and WMV-2 caused only slight wilt.
\end{abstract}

(Received June 27, 1988)

Key words: wilt, cucumber, cucumber mosaic virus, watermelon mosaic virus-2, zucchini yellow mosaic virus.

\section{INTRODUCTION}

In Japan, grafting of cucumber plants on squash rootstocks is widely practiced for the prevention of the occurrence of Fusarium wilt and Phytophthora rot on cucumber plants, because squash rootstocks are resistant to these pathogens. Wilt diseases were observed on cucumber plants grafted on squash rootstocks in Kagawa, Japan in the autumn of 1986. Wilted plants showed also mosaic symptoms on the upper leaves, while no fungal organisms were detected in the xylem of the stems and roots. Based on these observations, it was considered that the wilt of the grafted cucumber plants may be caused by a virus infection. In Japan, cucumber green mottle mosaic virus, cucumber mosaic virus (CMV), cucumber yellows virus, watermelon mosaic virus-2 (WMV-2) and zucchini yellow mosaic virus (ZYMV) were reported from cucumber plants. The symptoms caused by these viruses consisted of mosaic, yellows and abnormality of fruits, but wilt symptoms were not included.

This study was carried out to identify the causal agent of wilt.

\footnotetext{
* Shikoku National Agricultural Experiment Station, Zentsuji, Kagawa 765, Japan
} 


\section{MATERIALS AND METHODS}

Collection of infected leaves. The upper leaves of 32 cucumber plants grafted on squash rootstocks, which showed wilt and mosaic symptoms on the upper leaves and no symptoms on the stems and roots, were collected in 10 fields in Kagawa, Japan from September to October 1986. The sap of these leaves was inoculated to cucumber seedlings (Cucumis sativus, cultivar Sagamihanjiro), and the infected leaf samples were used for virus detection by the enzyme-linked immunosorbent assay (ELISA) and inoculation tests.

Detection of virus. The simplified ELISA ${ }^{4)}$ was used. The well was coated with $\gamma$ globulin at $37 \mathrm{C}$ for $4 \mathrm{hr}$, and $0.1 \mathrm{ml}$ each of the sample and conjugate was simultaneously incubated in a well at $5 \mathrm{C}$ for $16 \mathrm{hr}$. Antiserum to CMV, ZYMV and WMV-2 was used for ELISA.

For the observation of the virus particles under the electron microscope, the sap of the infected leaf samples was stained with $2 \%$ phosphotungstic acid, $\mathrm{pH} 7.0$.

$C M V, Z Y M V$ and WMV-2 isolates. For the isolation of CMV from the leaf samples infected with CMV and ZYMV, or CMV, ZYMV and WMV-2, the leaf sap was inoculated to Nicotiana glutinosa. Then 6 single lesion isolates of CMV were obtained by three successive single lesion transfers in Chenopodium amaranticolor.

For the isolation of ZYMV from the leaf samples infected with CMV and ZYMV, the leaf sap diluted at $1 / 100(w / v)$ and $\gamma$-globulin of CMV-antiserum at the concentration of $0.1 \mathrm{mg} / \mathrm{ml}$ were mixed in the same volume and incubated at $30 \mathrm{C}$ for $24 \mathrm{hr}$ to neutralize CMV. The mixture of the sap and CMV-antiserum was inoculated to cucumber seedlings and 4 single lesion isolates of ZYMV were obtained by three successive single lesion transfers in C. amaranticolor. Another 5 isolates of ZYMV were also obtained from the leaf sample singly infected with ZYMV by serial single lesion transfer in C. amaranticolor.

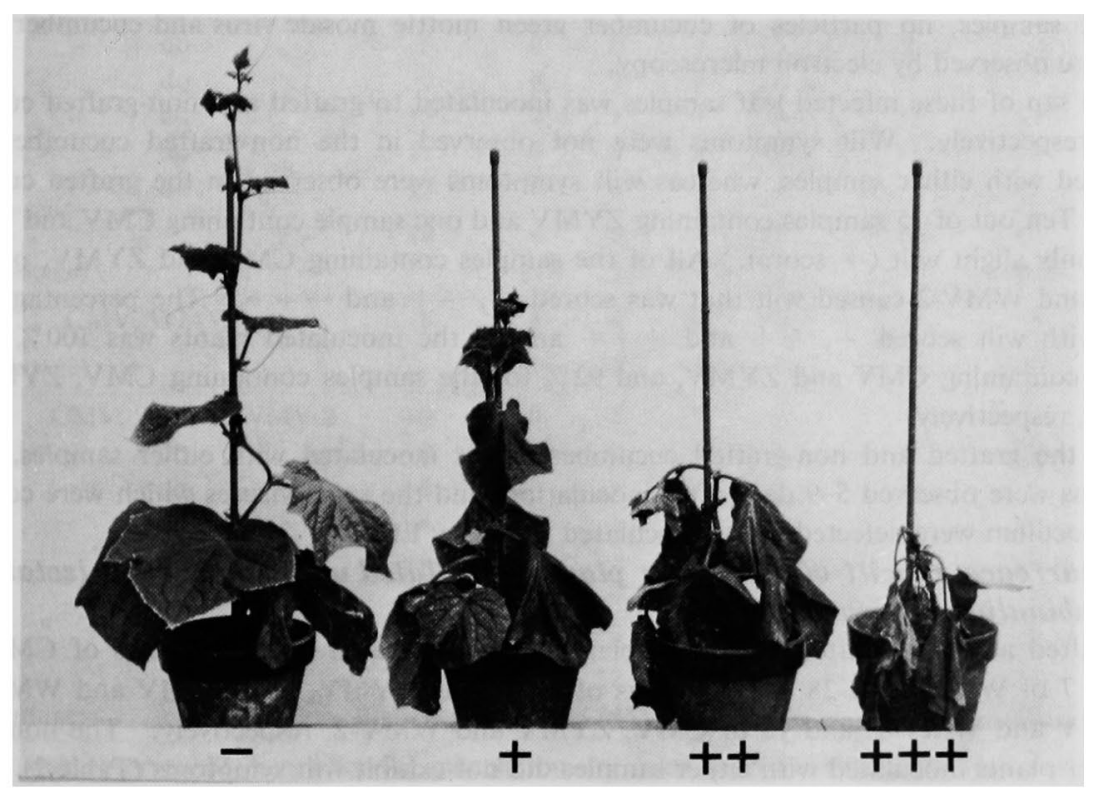

Fig. 1. Grading of severity of wilt in the grafted cucumber plants. $-=$ no wilt, $+=$ slight wilt, $++=$ wilt and no plant death, $+++=$ wilt and plant death. The grafted cucumber plants were inoculated with a combination of $42 \mathrm{CM}$ isolate of CMV and $5 Z Y$ isolate of ZYMV (see Table 2). 
The isolates of CMV and ZYMV were identified as CMV and ZYMV, respectively, based on the host range, particle morphology, serology and aphid transmission tests ${ }^{3)}$.

WMV-2 used in the tests to identify the causal virus of wilt consisted of the seven isolates identified by Yamamoto et al. ${ }^{\text {,8) }}$

The isolates of CMV were maintained in N. glutinosa, and the isolates of ZYMV and WMV-2 were maintained in the cucumber plants by serial sap inoculation.

Inoculation of virus on grafted and non-grafted cucumber plants. Nine-day-old cucumber seedlings were grafted on 6-day-old squash (hybrid of Cucurbita maxima $\times$ C. moschata, cultivar Shintosa) rootstocks by using the approach grafting method. Each of the grafted and nongrafted cucumber plants was transplanted in a clay pot $(15 \mathrm{~cm}$ diameter) and grown in a greenhouse at 20-30 C. Six isolates of CMV, 9 of ZYMV and 7 of WMV-2 were employed for the inoculation. On the 16th-22nd day after grafting, the 3rd or 4th leaf of 6 to 33 grafted and non-grafted cucumber plants was inoculated with a single isolate or a mixture of virus isolates. For single virus inoculation, the sap of the infected leaves was diluted at $1 / 10$ to $1 / 15(\mathrm{w} / \mathrm{v})$, and for the mixed inoculation with two or three viruses, the sap (diluted at 1/5) of the infected leaves with a single virus was mixed in the same volume.

The severity of wilt in the inoculated plants was observed after sunset on the 12th to 14th day after inoculation. The severity of wilt was classified into 4 grades, i.e. $-=$ no wilt, $t=$ slight wilt, $++=$ wilt and no plant death, $+++=$ wilt and plant death (Fig. 1).

\section{RESULTS}

Relationship between virus detection in the wilted cucumber plants collected in the field and the occurrence of wilt on cucumber plants inoculated with these samples

CMV, ZYMV and WMV-2 were detected by ELISA in the cucumber plants showing wilt symptoms in the fields. Among the 32 samples, 15 samples were infected with ZYMV, 9 with CMV and ZYMV, 7 with CMV, ZYMV and WMV-2, and 1 with CMV and WMV-2 (Table 1). In those samples, no particles of cucumber green mottle mosaic virus and cucumber yellows virus were observed by electron microscopy.

The sap of these infected leaf samples was inoculated to grafted and non-grafted cucumber plants, respectively. Wilt symptoms were not observed in the non-grafted cucumber plants inoculated with either samples, whereas wilt symptoms were observed in the grafted cucumber plants. Ten out of 15 samples containing ZYMV and one sample containing CMV and WMV-2 caused only slight wilt (+ score). All of the samples containing CMV and ZYMV, or CMV, ZYMV and WMV-2 caused wilt that was scored,+++ and +++ . The percentage of the plants with wilt scored,+++ and +++ among the inoculated plants was $100 \%$ for the samples containing CMV and ZYMV, and $92 \%$ for the samples containing CMV, ZYMV and WMV-2, respectively.

On the grafted and non-grafted cucumber plants inoculated with either samples, mosaic symptoms were observed 5-9 days after inoculation, and the same viruses which were contained in the inoculum were detected in the inoculated plants by ELISA.

Occurrence of wilt of cucumber plants inoculated with single virus isolates or a combination of viruses

Grafted and non-grafted cucumber plants were inoculated with 6 isolates of CMV, 9 of ZYMV, 7 of WMV-2, or 28 combinations of CMV and ZYMV, 16 of CMV and WMV-2, 10 of ZYMV and WMV-2, and 12 of CMV, ZYMV and WMV-2, respectively. The non-grafted cucumber plants inoculated with either samples did not exhibit wilt symptoms (Table 2). In the grafted cucumber plants, CMV or WMV-2, and a combination of ZYMV and WMV-2 did not cause wilt. Two isolates among 9 of ZYMV, and 4 among 16 combinations of CMV and WMV-2 caused only slight wilt with a + score in the plants. The percentage of the plants showing slight wilt among the inoculated ones was $3 \%$ for the $9 \mathrm{ZYMV}$ isolates, and $8 \%$ for the 16 combinations 
Table 1. Relationship between virus detection in the cucumber plants showing wilt symptoms in the field and the occurrence of wilt in cucumber plants grafted and non-grafted on squash rootstocks by the inoculation with these samples

\begin{tabular}{|c|c|c|c|c|c|c|c|c|c|}
\hline \multirow{3}{*}{$\begin{array}{c}\text { Leaf } \\
\text { sample }\end{array}$} & \multirow{3}{*}{$\begin{array}{c}\text { Virus } \\
\text { detected } \\
\text { by ELISA }\end{array}$} & \multicolumn{5}{|c|}{ Grafted plants } & \multicolumn{3}{|c|}{ Non-grafted plants } \\
\hline & & \multirow{2}{*}{$\begin{array}{l}\text { Number } \\
\text { of plants } \\
\text { inoculated }\end{array}$} & \multicolumn{4}{|c|}{ Severity of wilt $a$ ) } & \multirow{2}{*}{$\begin{array}{l}\text { Number } \\
\text { of plants } \\
\text { inoculated }\end{array}$} & \multicolumn{2}{|c|}{ Severity of wilt a) } \\
\hline & & & - & + & ++ & +++ & & -+ & $+\sim+++$ \\
\hline No. 11 & ZYMV & 6 & 6 & $\mathbf{0}$ & 0 & 0 & 6 & 6 & $\mathbf{0}$ \\
\hline No. 22 & do & 7 & 7 & 0 & 0 & 0 & 7 & 7 & 0 \\
\hline No. 23 & do & 13 & 11 & 2 & 0 & 0 & 13 & 13 & 0 \\
\hline No. 24 & do & 7 & 5 & 2 & 0 & $\mathbf{0}$ & 7 & 7 & 0 \\
\hline No. 26 & do & 12 & 11 & 1 & 0 & 0 & 12 & 12 & 0 \\
\hline No. 28 & do & 11 & 10 & 1 & 0 & 0 & 11 & 11 & 0 \\
\hline No. 30 & do & 7 & 7 & 0 & 0 & 0 & 7 & 7 & 0 \\
\hline No. 31 & do & 6 & 5 & 1 & 0 & 0 & 6 & 6 & 0 \\
\hline No. 32 & do & 6 & 4 & 2 & 0 & 0 & 6 & 6 & 0 \\
\hline No. 33 & do & 6 & 5 & 1 & 0 & 0 & 6 & 6 & 0 \\
\hline No. 34 & do & 6 & 6 & 0 & 0 & 0 & 6 & 6 & 0 \\
\hline No. 37 & do & 6 & 5 & 1 & 0 & 0 & 6 & 6 & 0 \\
\hline No. 38 & do & 11 & 10 & 1 & 0 & 0 & 11 & 11 & 0 \\
\hline No. 39 & do & 6 & 4 & 2 & 0 & 0 & 6 & 6 & 0 \\
\hline No. 40 & do & 6 & 6 & 0 & 0 & 0 & 6 & 6 & 0 \\
\hline \multicolumn{2}{|c|}{$\begin{array}{l}\text { Total } \\
\quad \text { (Percentage) }\end{array}$} & 116 & $\begin{array}{c}102 \\
(88 \%\end{array}$ & $\begin{array}{l}14 \\
12 \%\end{array}$ & $\begin{array}{l}0 \\
0 \%\end{array}$ & $\begin{array}{l}0 \\
0 \%)\end{array}$ & 116 & $\begin{array}{l}116 \\
(100 \%\end{array}$ & $\begin{array}{l}0 \\
0 \%)\end{array}$ \\
\hline No. 5 & CMV, ZYMV & 6 & 0 & 0 & 3 & 3 & 6 & 6 & 0 \\
\hline No. 15 & do & 10 & 0 & 0 & 0 & 10 & 10 & 10 & 0 \\
\hline No. 17 & do & 6 & 0 & 1 & 3 & 2 & 6 & 6 & 0 \\
\hline No. 20 & do & 6 & 0 & 1 & 3 & 2 & 6 & 6 & 0 \\
\hline No. 21 & do & 6 & 0 & $\mathbf{0}$ & 3 & 3 & 6 & 6 & 0 \\
\hline No. 25 & do & 7 & 0 & 1 & 0 & 6 & 7 & 7 & 0 \\
\hline No. 27 & do & 13 & 0 & 1 & 4 & 8 & 13 & 13 & 0 \\
\hline No. 29 & do & 11 & 0 & 0 & 2 & 9 & 11 & 11 & 0 \\
\hline No. 42 & do & 15 & 0 & 0 & 1 & 14 & 15 & 15 & 0 \\
\hline \multicolumn{2}{|c|}{$\begin{array}{l}\text { Total } \\
\text { (Percentage) }\end{array}$} & 80 & $\begin{array}{c}0 \\
0 \%\end{array}$ & $\begin{array}{l}4 \\
5 \%\end{array}$ & $\begin{array}{l}19 \\
24 \%\end{array}$ & $\begin{array}{l}57 \\
71 \%)\end{array}$ & 80 & $\begin{array}{c}80 \\
(100 \%\end{array}$ & $\begin{array}{l}0 \\
0 \%)\end{array}$ \\
\hline No. 4 & $\overline{C M V}$, WMV-2 & 8 & 4 & 4 & 0 & 0 & 8 & 8 & 0 \\
\hline \multicolumn{2}{|c|}{ (Percentage) } & & $(50 \%$ & $50 \%$ & $0 \%$ & $0 \%)$ & & $(100 \%$ & $0 \%)$ \\
\hline No. 3 & CMV, ZYMV, WMV-2 & 9 & 0 & 1 & 4 & 4 & 9 & 9 & 0 \\
\hline No. 12 & do & 10 & 0 & 0 & 3 & 7 & 10 & 10 & 0 \\
\hline No. 13 & do & 6 & 0 & 1 & 3 & 2 & 6 & 6 & $\mathbf{0}$ \\
\hline No. 14 & do & 6 & 0 & 3 & 1 & 2 & 6 & 6 & 0 \\
\hline No. 16 & do & 6 & 1 & 1 & 3 & 1 & 6 & 6 & 0 \\
\hline No. 18 & do & 8 & 3 & 4 & 1 & 0 & 8 & 8 & 0 \\
\hline No. 19 & do & 6 & 0 & 2 & 3 & 1 & 6 & 6 & 0 \\
\hline $\begin{array}{l}\text { Total } \\
\text { (Perce }\end{array}$ & age) & 51 & $\begin{array}{c}4 \\
(8 \%\end{array}$ & $\begin{array}{l}12 \\
24 \%\end{array}$ & $\begin{array}{l}18 \\
35 \%\end{array}$ & $\begin{array}{l}17 \\
33 \%)\end{array}$ & 51 & $\begin{array}{c}51 \\
(100 \%\end{array}$ & $\begin{array}{l}0 \\
0 \% \text { ) }\end{array}$ \\
\hline
\end{tabular}

a) Wilt was observed 12 days after the inoculation. $-=$ no wilt, $+=$ slight wilt, $++=$ wilt and no plant death, $+++=$ wilt and plant death. 
Table 2. Occurrence of wilt in grafted and non-grafted cucumber plants inoculated with a single or a combination of CMV, ZYMV and WMV-2

\begin{tabular}{|c|c|c|c|c|c|c|c|c|c|c|}
\hline & Virus isola & & & Grafte & plan & & & Non-g & grafted p & lants \\
\hline & & & Number & Ser & erity $c$ & f wilt & & Number & Severity & of wilt ${ }^{a}$ ) \\
\hline Car & $21 \mathrm{NV}$ & WIV $\quad$ - & inoculated & - & + & ++ & +++ & inoculated & -+ & $+\sim+t$ \\
\hline $3 \mathrm{CM}$ & - & - & 6 & 6 & 0 & 0 & 0 & 6 & 6 & 0 \\
\hline $5 \mathrm{CM}$ & - & - & 12 & 12 & 0 & 0 & 0 & 12 & 12 & 0 \\
\hline $14 \mathrm{CM}$ & - & - & 6 & 6 & 0 & 0 & 0 & 6 & 6 & 0 \\
\hline $21 \mathrm{CM}$ & - & - & 20 & 20 & 0 & 0 & 0 & 20 & 20 & 0 \\
\hline $29 \mathrm{CM}$ & - & - & 12 & 12 & 0 & 0 & 0 & 12 & 12 & 0 \\
\hline $42 \mathrm{CM}$ & - & - & 26 & 26 & 0 & 0 & 0 & 26 & 26 & 0 \\
\hline $\begin{array}{l}\text { Total } \\
(\text { Perc }\end{array}$ & age) & & 82 & $\begin{array}{c}82 \\
(100 \% \\
\end{array}$ & $\begin{array}{l}0 \\
0 \% \\
\end{array}$ & $\begin{array}{l}0 \\
0 \%\end{array}$ & $\begin{array}{l}0 \\
0 \%) \\
\end{array}$ & 82 & $\begin{array}{c}82 \\
(100 \% \\
\end{array}$ & $\begin{array}{l}0 \\
0 \%) \\
\end{array}$ \\
\hline- & $5 Z Y$ & - & 24 & 24 & 0 & 0 & 0 & 24 & 24 & 0 \\
\hline- & $11 \mathrm{ZY}$ & - & 6 & 6 & 0 & 0 & 0 & 6 & 6 & 0 \\
\hline 一 & $21 Z Y$ & 一 & 7 & 5 & 2 & 0 & 0 & 7 & 7 & 0 \\
\hline- & $22 Z Y$ & - & 6 & 6 & 0 & 0 & 0 & 6 & 6 & 0 \\
\hline- & $29 \mathrm{ZY}$ & - & 12 & 12 & 0 & 0 & 0 & 12 & 12 & 0 \\
\hline- & $30 Z Y$ & - & 6 & 6 & 0 & 0 & 0 & 6 & 6 & 0 \\
\hline- & $34 Z Y$ & - & 6 & 6 & 0 & 0 & 0 & 6 & 6 & 0 \\
\hline- & $39 Z Y$ & - & 6 & 6 & 0 & 0 & 0 & 6 & 6 & 0 \\
\hline- & $42 \mathrm{ZY}$ & - & 31 & 30 & 1 & 0 & 0 & 31 & 31 & 0 \\
\hline $\begin{array}{l}\text { Total } \\
\text { (Perc }\end{array}$ & age) & & 104 & $\begin{array}{l}101 \\
(97 \% \\
\end{array}$ & $\begin{array}{l}3 \\
3 \% \\
\end{array}$ & $\begin{array}{l}0 \\
0 \% \\
\end{array}$ & $\begin{array}{l}0 \\
0 \%)\end{array}$ & 104 & $\begin{array}{l}104 \\
(100 \% \\
\end{array}$ & $\begin{array}{l}0 \\
0 \%) \\
\end{array}$ \\
\hline- & - & $9(\mathrm{M})$ & 12 & 12 & 0 & 0 & 0 & 12 & 12 & 0 \\
\hline- & - & 81 & 6 & 6 & 0 & 0 & 0 & 6 & 6 & 0 \\
\hline- & - & 82 & 6 & 6 & 0 & 0 & 0 & 6 & 6 & 0 \\
\hline- & - & 83 & 6 & 6 & 0 & 0 & 0 & 6 & 6 & 0 \\
\hline- & - & 82019 & 6 & 6 & 0 & 0 & 0 & 6 & 6 & 0 \\
\hline- & - & 82022 & 6 & 6 & 0 & 0 & 0 & 6 & 6 & 0 \\
\hline- & - & 82023 & 6 & 6 & 0 & 0 & 0 & 6 & 6 & 0 \\
\hline $\begin{array}{l}\text { Total } \\
\text { (Perc }\end{array}$ & & & 48 & $\begin{array}{c}48 \\
(100 \% \\
\end{array}$ & $\begin{array}{l}0 \\
0 \% \\
\end{array}$ & $\begin{array}{l}0 \\
0 \% \\
\end{array}$ & $\begin{array}{l}0 \\
0 \%)\end{array}$ & 48 & $\begin{array}{c}48 \\
<100 \% \\
\end{array}$ & $\begin{array}{l}0 \\
0 \%) \\
\end{array}$ \\
\hline $3 \mathrm{CM}$ & $5 Z Y$ & - & 12 & 8 & 4 & 0 & 0 & 12 & 12 & 0 \\
\hline do & $42 \mathrm{ZY}$ & - & 6 & 1 & 5 & 0 & 0 & 6 & 6 & 0 \\
\hline $5 \mathrm{CM}$ & $5 Z Y$ & - & 12 & 1 & 4 & 0 & 7 & 12 & 12 & 0 \\
\hline do & $42 Z Y$ & - & 6 & 0 & 0 & 1 & 5 & 6 & 6 & 0 \\
\hline $14 \mathrm{CM}$ & $5 Z Y$ & - & 6 & 0 & 1 & 4 & 1 & 6 & 6 & 0 \\
\hline do & $29 Z Y$ & - & 6 & 0 & 0 & 2 & 4 & 6 & 6 & 0 \\
\hline do & $42 Z Y$ & - & 12 & 0 & 0 & 1 & 11 & 12 & 12 & 0 \\
\hline $21 \mathrm{CM}$ & $5 Z Y$ & - & 22 & 19 & 3 & 0 & 0 & 22 & 22 & 0 \\
\hline do & $11 Z Y$ & - & 6 & 1 & 4 & 0 & 1 & 6 & 6 & 0 \\
\hline do & $21 Z Y$ & - & 9 & 0 & 2 & 1 & 6 & 9 & 9 & 0 \\
\hline do & $22 Z Y$ & - & 6 & 0 & 2 & 4 & 0 & 6 & 6 & 0 \\
\hline do & $29 \mathrm{ZY}$ & - & 10 & 2 & 5 & 2 & 1 & 10 & 10 & 0 \\
\hline do & $30 Z Y$ & - & 7 & 0 & 3 & 3 & 1 & 7 & 7 & 0 \\
\hline do & $34 Z Y$ & - & 6 & 0 & 0 & 5 & 1 & 6 & 6 & 0 \\
\hline do & $39 \mathrm{ZY}$ & - & 7 & 1 & 1 & 5 & 0 & 7 & 7 & 0 \\
\hline do & $42 Z Y$ & - & 15 & 4 & 7 & 2 & 2 & 15 & 15 & 0 \\
\hline $29 \mathrm{CM}$ & $5 Z Y$ & - & 6 & 0 & 1 & 3 & 2 & 6 & 6 & 0 \\
\hline
\end{tabular}


Table 2. (Continued)

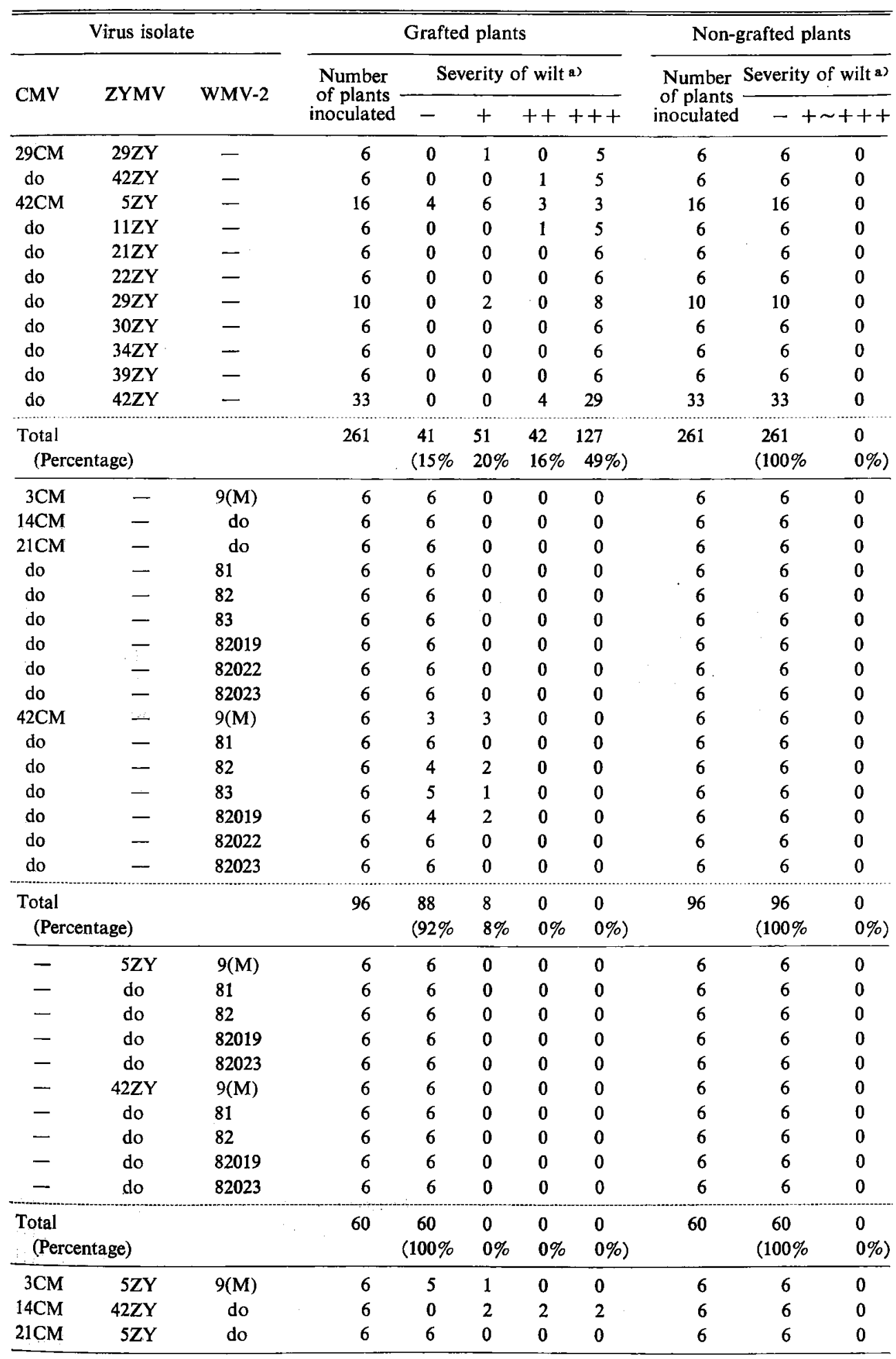


Table 2. (Continued)

\begin{tabular}{|c|c|c|c|c|c|c|c|c|c|c|}
\hline \multicolumn{3}{|c|}{ Virus isolate } & \multicolumn{5}{|c|}{ Grafted plants } & \multicolumn{3}{|c|}{ Non-grafted plants } \\
\hline \multirow{2}{*}{ CMV } & \multirow{2}{*}{ ZYMV } & \multirow{2}{*}{ WMV-2 } & \multirow{2}{*}{$\begin{array}{l}\text { Number } \\
\text { of plants } \\
\text { inoculated }\end{array}$} & \multicolumn{4}{|c|}{ Severity of wilt a) } & \multirow{2}{*}{$\begin{array}{l}\text { Number } \\
\text { of plants } \\
\text { inoculated }\end{array}$} & \multicolumn{2}{|c|}{ Severity of wilt a) } \\
\hline & & & & - & + & ++ & +++ & & -+ & $+\sim+++$ \\
\hline $21 \mathrm{CM}$ & $5 Z Y$ & 81 & 6 & 6 & 0 & 0 & 0 & 6 & 6 & 0 \\
\hline do & do & 82 & 6 & 6 & 0 & 0 & 0 & 6 & 6 & $\mathbf{0}$ \\
\hline do & do & 82019 & 6 & 6 & $\mathbf{0}$ & 0 & 0 & 6 & 6 & 0 \\
\hline do & do & 82023 & 6 & 6 & 0 & 0 & 0 & 6 & 6 & 0 \\
\hline $42 \mathrm{CM}$ & $42 Z Y$ & $9(\mathrm{M})$ & 6 & 0 & 1 & 3 & 2 & 6 & 6 & 0 \\
\hline do & do & 81 & 6 & 1 & 0 & 4 & 1 & 6 & 6 & 0 \\
\hline do & do & 82 & 6 & 0 & 1 & 2 & 3 & 6 & 6 & 0 \\
\hline do & do & 82019 & 6 & 0 & 2 & 0 & 4 & 6 & 6 & 0 \\
\hline do & do & 82023 & 6 & 0 & 1 & 2 & 3 & 6 & 6 & 0 \\
\hline $\begin{array}{l}\text { Total } \\
\text { (Perc }\end{array}$ & ge) & & 72 & $\begin{array}{l}36 \\
(50 \%\end{array}$ & $\begin{array}{c}8 \\
11 \%\end{array}$ & $\begin{array}{l}13 \\
18 \%\end{array}$ & $\begin{array}{l}15 \\
21 \%)\end{array}$ & 72 & $\begin{array}{c}72 \\
(100 \%\end{array}$ & $\begin{array}{l}0 \\
0 \% \text { ) }\end{array}$ \\
\hline
\end{tabular}

a) Wilt was observed 14 days after the inoculation. $-=$ no wilt, $+=$ slight wilt, $++=$ wilt and no plant death, $+++=$ wilt and plant death.

of CMV and WMV-2. All of the 28 combinations of CMV and ZYMV caused wilt that was scored,+++ and +++ , and 25 out of 28 combinations caused wilt scored ++ and +++ on the grafted cucumber plants. The percentage of the plants showing wilt scored,+++ and +++ among the inoculated ones was $85 \%$. Among the 12 combinations of CMV, ZYMV and WMV-2, 5 did not cause wilt, 1 caused slight wilt ( + score), and 6 caused wilt scored ++ and +++ on the grafted cucumber plants. The percentage of the plants showing wilt scored ,+++ and +++ among the inoculated ones was $50 \%$.

On the grafted and non-grafted cucumber plants inoculated with a single isolate of CMV, ZYMV or WMV-2, and a combination of CMV and ZYMV; CMV and WMV-2; ZYMV and WMV-2; CMV, ZYMV and WMV-2, mosaic symptoms were observed 5-9 days after inoculation, and on the 10th day after inoculation a single virus and two or three viruses used for the inoculation were detected by ELISA in the inoculated plants, grafted and non-grafted cucumber plants, respectively.

\section{DISCUSSION}

The occurrence of wilt with a severity ranging from slight to plant death was observed in the grafted cucumber plants in the field. In the wilted plants, the upper leaves always showed mosaic symptoms. For the experiments, the upper leaves with mosaic symptoms were collected at a height of $1.5 \mathrm{~m}$ from grafted cucumber plants showing slight wilt or wilt without plant death in the fields. The collected leaves were infected with ZYMV alone, or with either of 3 combinations of viruses; CMV and ZYMV; CMV and WMV-2; CMV, ZYMV and WMV-2. By sap inoculation, none of the samples caused wilt on the non-grafted cucumber plants. All of the samples containing CMV and ZYMV, or CMV, ZYMV and WMV-2 caused wilt that was scored ++ and +++ , and one sample containing CMV and WMV-2 caused slight wilt ( + score). However, among the 15 samples infected with ZYMV, 10 caused slight wilt (+ score), and 5 did not cause wilt. Since the symptoms of wilt were observed 12 days after the inoculation in the experiments, it is considered that the 5 samples infected with ZYMV which did not cause wilt experimentally were able to induce wilt after a long period of infection under field conditions.

To identify the causal virus of wilt, the grafted and non-grafted cucumber plants were inoculated with either a single or a combination of CMV, ZYMV and WMV-2 isolates. In the non- 
grafted cucumber plants, the inoculation with either samples did not cause wilt. In the grafted cucumber plants, 2 out of 9 isolates of ZYMV or 4 out of 16 combinations of CMV and WMV-2 caused slight wilt ( + score). All of the 28 combinations of CMV and ZYMV, and 7 out of 12 combinations of CMV, ZYMV and WMV-2 caused wilt that was scored,+++ and +++ . These results coincided with those obtained in the inoculation tests of the samples collected in the field. Based on these results, it was concluded that mixed infection with CMV and ZYMV, or CMV, ZYMV and WMV-2, caused severe wilt at a high frequency and single infection with ZYMV or mixed infection with CMV and WMV-2 caused only slight wilt in the grafted cucumber plants.

Single infection with CMV or WMV-2, and mixed infection with ZYMV and WMV-2 were not observed in the samples collected in the field (Table 1). By the inoculation test, single CMV or WMV-2 isolate, or a combination of ZYMV and WMV-2 isolates did not cause wilt (Table 2). Therefore, it was assumed that the infection with CMV or WMV-2, and the combination of ZYMV and WMV-2 did not cause wilt on the grafted cucumber plants in the field.

The addition of WMV-2 to the combination of CMV and ZYMV reduced the severity of wilt (Tables 1 and 2). As shown in Table 2, the combination of $42 \mathrm{CM}$ isolate of $\mathrm{CMV}$ and 42ZY isolate of ZYMV caused severe wilt ( +++ score) on 29 out of 33 grafted cucumber plants, whereas the mixture of that combination and one WMV-2 isolate of $9(\mathrm{M}), 81,82,82019$ and 82023 caused severe wilt $(+++$ score) on 13 out of 30 grafted plants. Therefore, it was considered that WMV-2 exerted an inhibitory effect on the expression of wilt in the mixed infection with CMV, ZYMV and WMV-2, and that the mixed infection with CMV and ZYMV essentially caused wilt on the grafted cucumber plants.

In Japan, it is known that Phytophthora capsici $\left.{ }^{6}\right)$, Mycosphaerella melonis $\left.{ }^{6}\right)$, Fusarium oxysporum f. sp. lagenariae ${ }^{5,6)}$, Phomopsis sp. ${ }^{2)}$ and tylose ${ }^{1)}$ cause wilt on cucumber plants grafted on squash rootstocks. In addition to those agents, it was shown that mixed infection with CMV and ZYMV also caused wilt on plants grafted on squash rootstocks in the present study.

The combination of CMV and ZYMV did not cause wilt on the cucumber plants either grafted or non-grafted on the cucumber rootstocks (unpublished data). Therefore, it is suggested that mixed infection with viruses may affect the squash rootstocks, although the mechanism underlying the occurrence of wilt remains to be elucidated.

\section{Literature cited}

1. Hamaya, E. and Ogawa, K. (1973). Agric. Hortic. 48: 1593-1595.

2. Hashimoto, K., Yoshino, S., Inayama, M. and Shibukawa, S. (1985). Ann. Phytopath. Soc. Japan $51: 94$.

3. Iwasaki, M. and Inaba, T. (1988). Proc. Assoc. Pl. Protec. Shikoku 23: 61-71.

4. Iwasaki, M., Yamamoto, T., Katsube, T. and Inaba, T. (1987). Ibid. 22: 57-62.

5. Kiso, A. and Nomura, Y. (1982). Proc. Assoc. Pl. Prot. Kyushu 28: 50-53.

6. Kiso, A. and Tezuka, N. (1977). Kyushu Agric. Res. 39: 55-56.

7. Terami, F., Yamamoto, T. and Inouye, T. (1985). Ann. Phytopath. Soc. Japan 51: 83.

8. Yamamoto, T., Ishii, M., Katsube, T. and Ohata, K. (1984). Bull. Shikoku Natl. Agric. Exp. Stn. 44: 26-140.

\section{和 文 摘 要}

岩㱦真人・稲葉忠興 : ウイルスによるカポチャ台接ぎ木キュウリの萎调

1986 年, 香川県下でカボチャ台接ぎ木キュウリに原因不明の萎调症が発生した。萎调株の上位葉はモザ イク症状を呈していた。萎调株の上位葉を採取し，ウイルスの種類を調べた。萎调株はズッキー二黄斑モ ザイクウイルス (ZYMV) に単独感染, キュウリモザイクウイルス (CMV) と ZYMV に混合感染, CMV とカボチャモザイクウイルス-2(WMV-2) に混合感染，または，CMV,ZYMV, WMV-2 に混合感染してい た。これらの採取標本をカボチャ台接ぎ木キュウリと自根キュウリに计液接種した。自根キュウリではまっ 
たく萎调は生じなかった。これに対し，接ぎ木キュウリでは，ZYMV 単独感染またはCMVとWMV-2の 混合感染標本を接種すると低率で軽度の萎淍，CMV そ ZYMV の混合感染または CMV, ZYMV, WMV-2 の混合感染標本を接種すると高率で重度の萎调が生じた。次に, CMV, ZYMV, WMV-2 の単分離株を供試 し，各ウイルスを単独または混合して接ぎ木および自根キュウリに接種した。自根キュウリではいずれの接 種でむ萎调はまったく生じなかった。これに対し，接ぎ木キュウリでは，CMV またはWMV-2 の単独接 種, ZYMV とWMV-2 の混合接種では萎调は生じなかったが，ZYMV 単独接種または CMVと WMV-2 の混合接種では低率で軽度の萎调，CMV とZYMVの混合接種または CMV, ZYMV, WMV-2 の混合接種 では高率で重度の萎调が生じた。以上の結果から，カボチャ台接ぎ木キュウリがZYMVに単独感染または CMV とWMV-2 に混合感染すると低率で軽度の萎调, CMV と ZYMV に混合感染または CMV, ZYMV, WMV-2 に混合感染すると高率で重度の萎调が生ずることが判明した。 